\title{
MEMOIR
}

OF THE

\section{LIFE AND WORKS}

OF

\section{EDWARD NEWMAN}

F.L.S., F.Z.S., M. InIP. L.-C. ACAD., ETC.

BY HIS SON.

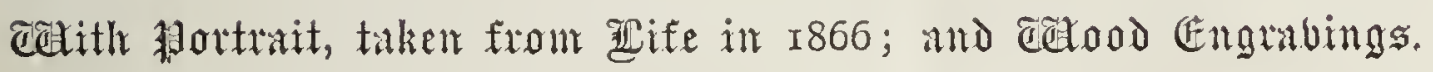

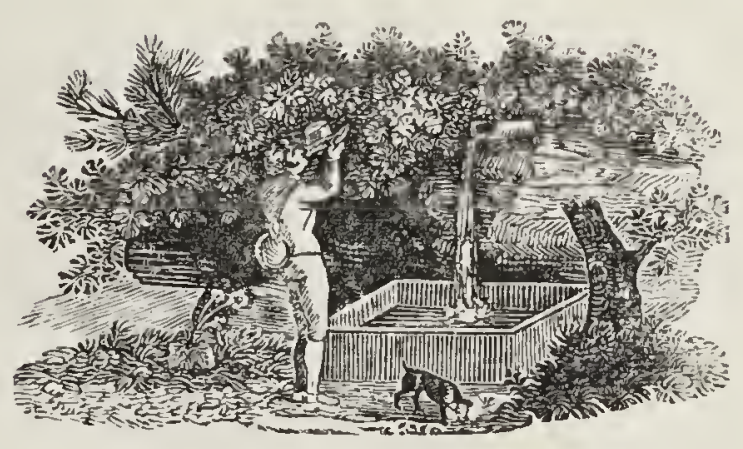

LONDON:

JOHN VAN VOORST, 1, PATERNOSTER ROW.

1876. 
LONDON:

T. I. NEWIAN, PIINIER, 32, BOTOLPH LINE, IASTCHEAR, E.C.

RB64680 


\section{A MEMOIR}

\section{OF \\ THE LIFE OF EDWARD NEWMAN,}

F.L.S., F.Z.S., M. IMP. L.-C. ACAD., ETC.

Edward Newanan was born at Hampstead on the 13th of May, 1801. His ancestor's became members of the Society of Friends at the rise of that sect in 1646, and several of them suffered imprisonment on account of their faitl, yet they have always remained stedfast to its tenets. His parents, George and Ann Newman, had four children, all sons, of whom Edward was the eldest. Botli father and mother liad a taste for Natural History, and early inculcated it in their children. One of his brother's writes:- "Edward's love for Natural History was born with him, and this natural taste was fostered by both parents. Our father encouraged us by daily conversation to observe all natural objects: he linew the notes of all the birds of the district, and imparted the knowledge to his children. I well remember him telling us at the brealifast-table that that morning he had heard the chiffchaff for the first time that year, or seen the whitethroat; and we used to record such events in our little note-books. White's 'Natural History of Selborne' was the beloved book of the family; that and 'Bewick's Birds' were referred to almost daily. Our mother tanght us the names of all the wild-plants as they came into blossom, and encouraged us to collect and study them." To these books may be added 'Bingley's Quadrupeds,' which was also a great favourite. He himself writes:- "I had a very, very early predilection for" butterflies; I may say even from my nurse's arms." And 
evidence of early work in Natural History appears in a minute memorandum-book, inscribed in large capitals on the first page:-_"Botany. E. Newman," without date, but written in pencil; at so early an age that each letter is formed separately, and occasional pages are devoted to "pothooks and hangers." The following is an extract:- "Of the geranium. The class is Monadelphia. The colour is various, being sometimes white, in other's scarlet; its leaf is round, but ragged; there are peppermint-scented and pencil-blossom. There are many other geraniums, but I do not know their names." Then follows a list of the Limnean divisions:- "Dodecandria, Icosandria, Polyandria (many), Didynamia (4), Tetradynamia (6)," \&c.

In the year 1812 he was sent to a boarding-school at Painswick, in Gloucestershire, of which Oade Roberts, a member of the Society of Friends, was master, where, in addition to being initiated into classical studies, his love for Natural History was developed. On "10th mo. 29, 1813," he writes home to his mother:- "I take great pleasure in botanizing, but there are not so many flowers as there were when I first came here to school; but still I find some. I shall have great pleasure in showing thee my botanical copy-books when I am at home." This is written in a small neat hand, very different from that in the memorandum-book mentioned above. On "2nd month 3rd, 1815," he is still at Painswick, and writes to a relative:"I could not give Helen much information with respect to lichens and mosses, as I have only yet studied the first classes; but I am now begimning to study the class Cryptogamia, though the snow has been on the ground ever since I returned." One of his schoolfellows, a cousin, writes:- "We were both initiated into a love for Natural History, which continued to interest us in after years; in his case eminently so. *** What particulariy impressed itself on my mind was the neatness and accuracy of Edward's drawing of a beetle,-so superior to what any of the rest of us could accomplish."

On leaving school, in the year 1817, he went to Godalming, in Surrey,-his mother's birthplace, - to which rural town his father, formerly in business in London as a manufacturer of morocco-leather, had removed on his retirenient. The family 
house is just outside the town, at the corner of the lane leading to Hatch. The father, however, seems to have been by no means tired of commercial life, for he again entered into business-this time at Godalming-as a wool stapler. This step was probably talien by the good man solely for the sake of his son, in order that on leaving school he might begin a commercial career under parental supervision. For ten years father and son continned in the wool trade; but the study of Nature-for which the neighbourhood of Godalming offered great opportunity-proved a strong counter-attraction to the younger man. He was not energetic in the routine of business, and it is to be feared that his absence from duty was frequent; nevertheless, he was far from idle. Indeed, idleness was foreign to his nature; not only at this period, but throughout life, idleness was in his opinion a positive crime. He held that no man need ever be without work. He knew scarcely any rest : if when he came home there were an interval of only a few minutes before a meal, out would come books, papers, and insect-boxes, and he would at once be deep in scientific work. He was generally in bed by ten o'clock at night, but up again in the very early morning; until his later years he was seldom in bed after six o'clock, and in summer-time he would often be up and at work by five, four, and even three o'clock. After 1840 the greater part of his writing was done before brealfast; he would also write from about seven to nine in the evening; but the greater part of the work was done in the uninterrupted quiet of the early morning.

It was in this spirit of industry that he wandered away from business at Godalming, and sought more congenial pursuits in the lanes and fields, the woods and commons, of the beautiful county of Surrey. Whether shooting blackcock on Hindhead, climbing old hollow trees for owlets, or wandering about the lanes with an insect-net, the mere present pleasure of the occupation was not the principal charm. "When the lengthening days give the first impulse to the feathered tribes to bend their course northward for the breeding season, it is here that I listen for the first notes of the chiffchaff: here I watch for the blackcap, the nightingale, the willow wrens, the garden warblers, 
the whitethroat; here, hour after hour, have I hunted for their nests, my object not being plunder, but information. Often have I covered my hand with scratches, from the prickles of briars and brambles, in my attempts to gain a satisfactory view of a nest and its contents without causing any disarrangement, well knowing how great was the risk of desertion if the parent birds should discover anything amiss; and, when deserted, if I knew not the builders, a nest was valueless. How well was I repaid for bleeding lands, if I discovered but one point in the history of a species. Egrs strung on bents are rife in all country plices; old nests are easy to be seen when the leaves

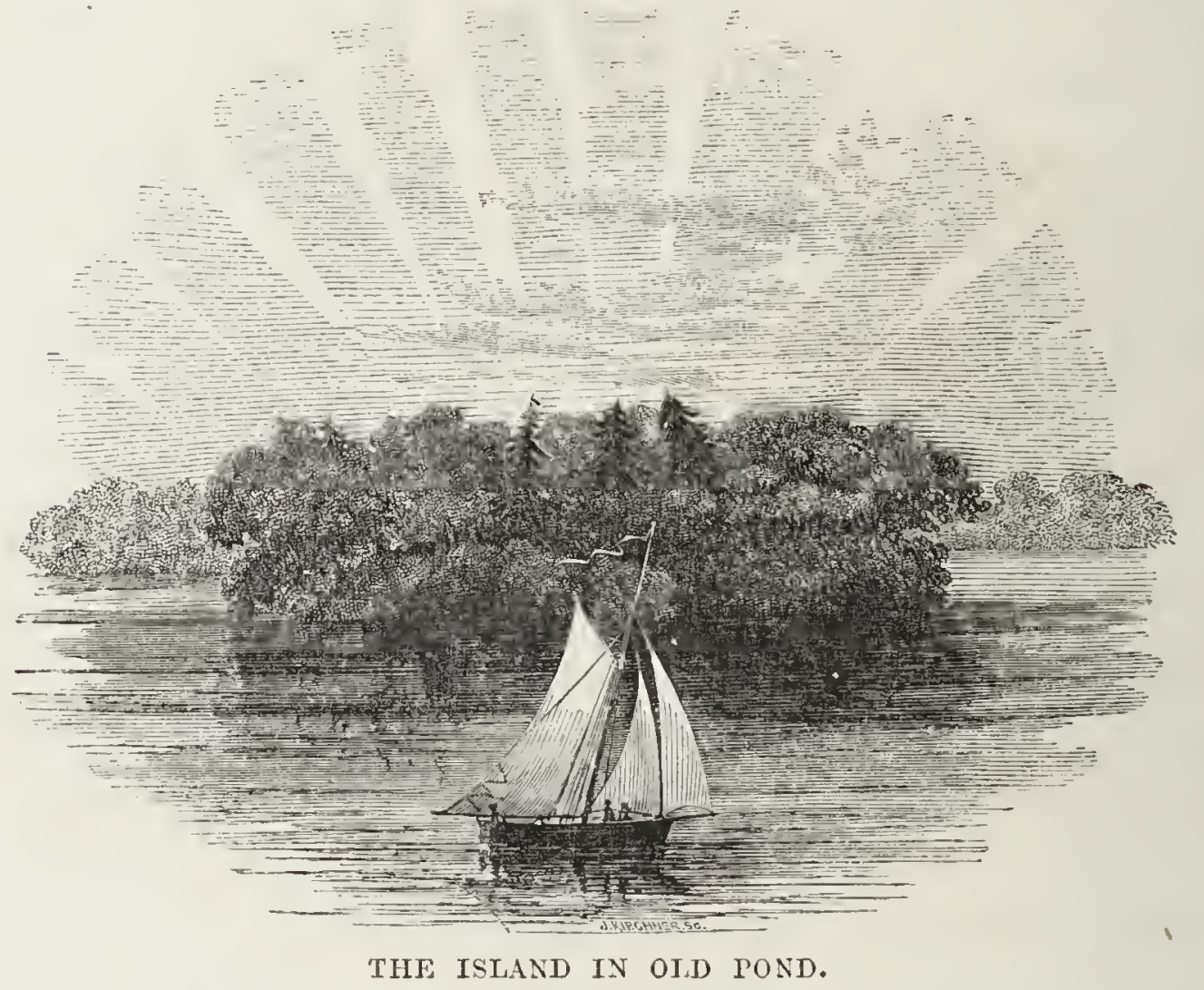

are gone; birds are plentiful in every hedge-row, and their song is the burthen of the passing breeze: but to connect with certainty each bird with its mate; to assign it the proper nest and proper eggs; to learn the exact time of its arrival and its departure; -all this is a study, a labour, rarely undertaken, and affords a pleasure alin to that which must be felt by a traveller exploring countries where man has not before trodden." Let the reader turn to the first chapter of the 'Letters of Rusticus,' from which the foregoing extract is taken, and observe with what microscopic, yet loving and living, detail the natural features of the neighbourhood of Godalming are pourtrayed. 
The piece of water called Old Pond was a most attractive spot to waterfowl; and an island in its centre was the resort of some of them in the breeding season, and also of a variety of other birds. It was on the property of his cousin, Mr. Robert Moline, and was a place he delighted to visit. No words can give so true an account of these ten years spent at Godalming as the 'Letters of Rusticus.' Extract after extract might be quoted, all to the point, and of exceeding interest.

It will be noticed that 'Rusticus' is here spoken of as the actual work of Mr. Newman. This brings forward the oncevexed question of the authorship of those charming 'Letters.'

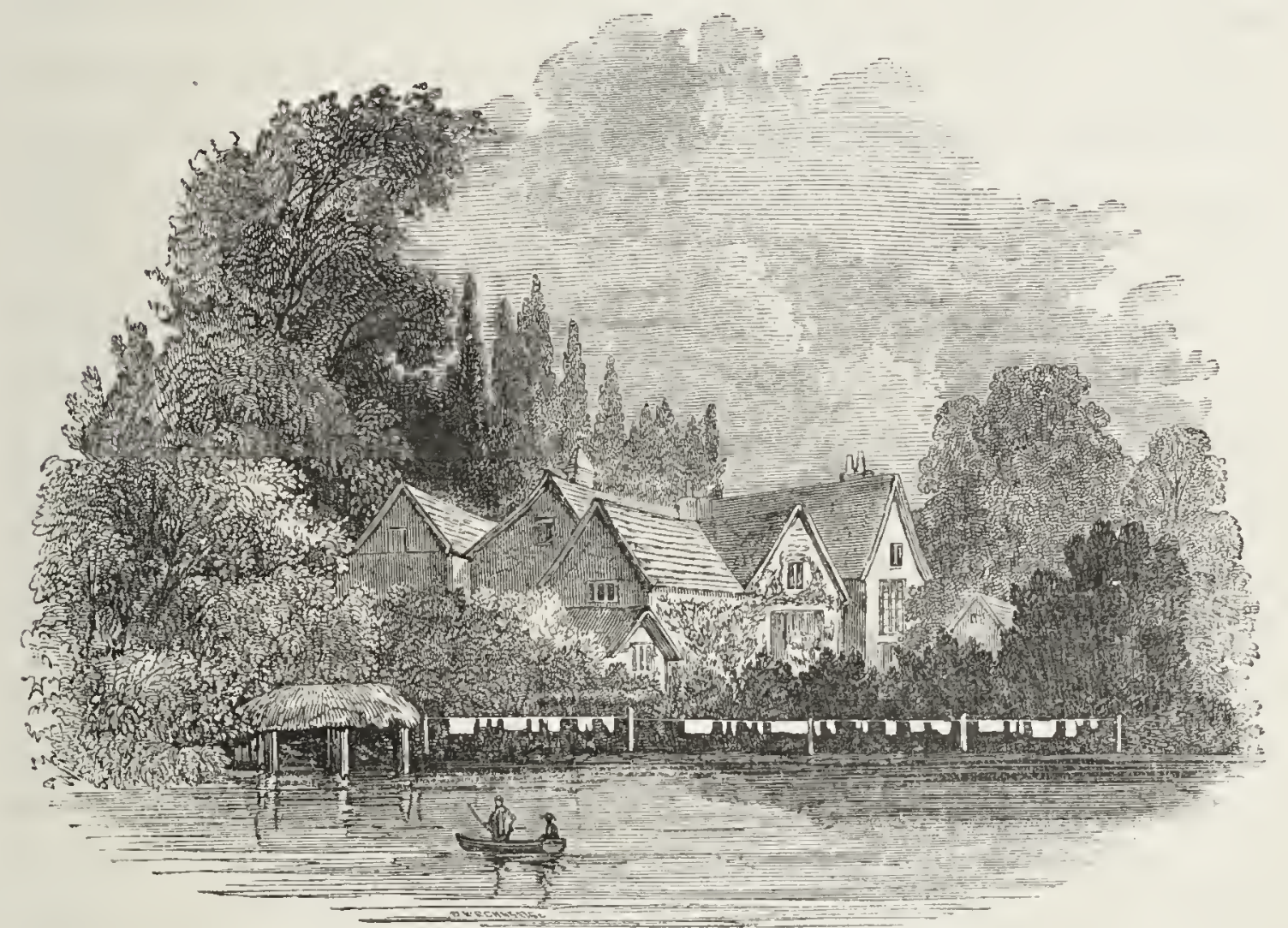

HATCH FROAL THE POND.

To few besides the author's near relatives has the secret been divulged; even Edward Doubleday, his nearest friend and second self, was kept in ignorance of the actual fact, although he, in common with most naturalists, had a shrewd suspicion. When the 'Letters' appeared in the 'Magazine of Natural History' and the 'Entomological Magazine' they caused quite a sensation in Godalming. Written by one who knew Godalming so well, who was so able a writer, as well as so skilled a naturalist; yet no one was able to discover the author. After much discussion they were finally attributed to 
the late Mr. J. D. Salmon. The veil may now be withdrawn, revealing Mr. Newman as the author of the whole. Much of the information on the birds and mammals of Godalming was, however, gleaned from his kind friend and frequent companion Waring Kidd, who, now in his eighty-eighth year, still lives at Godalming; and modesty prevented Mr. Newman from assuming the authorship when the facts were not all his own. The 'Letters' having been once begun under a nom de plume ('Magazine of Natural History,' 1832, vol. v. p. 601) it was convenient to continue the pleasant fiction. At the commencement of Appendix C to 'Letters of Rusticus,' Mr. Newman wrote:- "I have introduced above a very faithful representation of Hatch, so long the residence of Mr. Kidd. It was here that he cultivated Ornithology so successfully; and I was at that time a very frequent visitor to his bird-room, and spent many of the happiest hour's of my boyhood in receiving information in that much-loved apartment." It has probably escaped the notice of many that the last of these 'Letters' were published in 'Chambers' Journal' in 1850, and were on the house sparrow ; mice, rats, weasels and stoats; feathered mousers; and squirrels. In one branch of his "Observations," viz., the life-histories of insects injurious to agriculture, Rusticus was a pioneer: no such work had previously been attempted; and, great as is its value, few besides Mr. Newman and the late John Curtis have ever ventured upon it. These chapters on Economic Entomology were continued at irregular intervals in the 'Entomologist,' the 'Zoologist,' and the 'Field,' until almost the close of his life. A further reference to this will be found on a later page.

In the year 1826 the wool business at Godalming was abandoned. It had never been a very profitable concern; and the parent, now past middle life, was desirous of freedom from commercial occupation. The son had never taken to it kindly.

In the same year Mr. Newman came up to London, and entered into a rope business at Deptford. To a nature such as his-delighting in all the charms of a life in the country-the change to Deptford would have been most distasteful, had it not opened out further opportunities for the cultivation of 
friendships and society among men of his own tastes. The rope business was to a great extent managed by the foreman, who had held the same post in the wool business at Godalming. It was not allowed to become a drudgery, although to him commerce was never congenial. Only one day in each week was entirely devoted to its affairs; a small part of each of the remaining days sufficed. At the rope-walk he had a large garden, which he subsequently described as a place where everything grew as it liked. A large plot of ground was sown with the common red valerian, because of its attractiveness to insects; and here he would remain in one spot for an hour or more at a time, mute and motionless, intently studying the habits of some insect, until he had mastered the minutest detail.

At Deptford he had many friends; and of the friendships then formed many ceased only with life itself. Francis Walker, Edward and Henry Doubleday, John and William Christy, Samuel Hanson, and Dr. Bowerbank, were perhaps the most intimate. Not only amongst scientific men, but in the Society of Friends, and indeed in the whole parish, did he find congenial spirits. His keen wit, acute perception, his knowledge, and genial manner, rendered him a general favourite; yet he appeared all unconscious of the charm which he possessed. No one could entertain a greater contempt for shallowness and conceit,-for a man possessing knowledge only surface-deep who assumed to be an authority,-in fact, for "humbug" in any shape. He scorned to conceal his opinions for fear of giving offence, and did not spare chastisement wherever deserved. His pen was as powerful in caustic satire as in microscopic description; and it was brought to bear with effect in parish affairs, in which he took a keen interest. At one time a part of Deptford was without gas, and, curiously enough, as it seems to us in the present day, there was strong opposition to its introduction. He worked vigorously for the cause of light, and had the satisfaction of success.

During the period of his residence at Deptford he made many excursions with one or other of his chosen associates. Birchwood, in Kent-for many years the place at which the annual dinner of the Entomological Club was held, or, as he puts it, 
"duly solemnised" -was frequently visited. It was at the Bull Inn, Birchwood Corner, that the scene of the "Colloquia

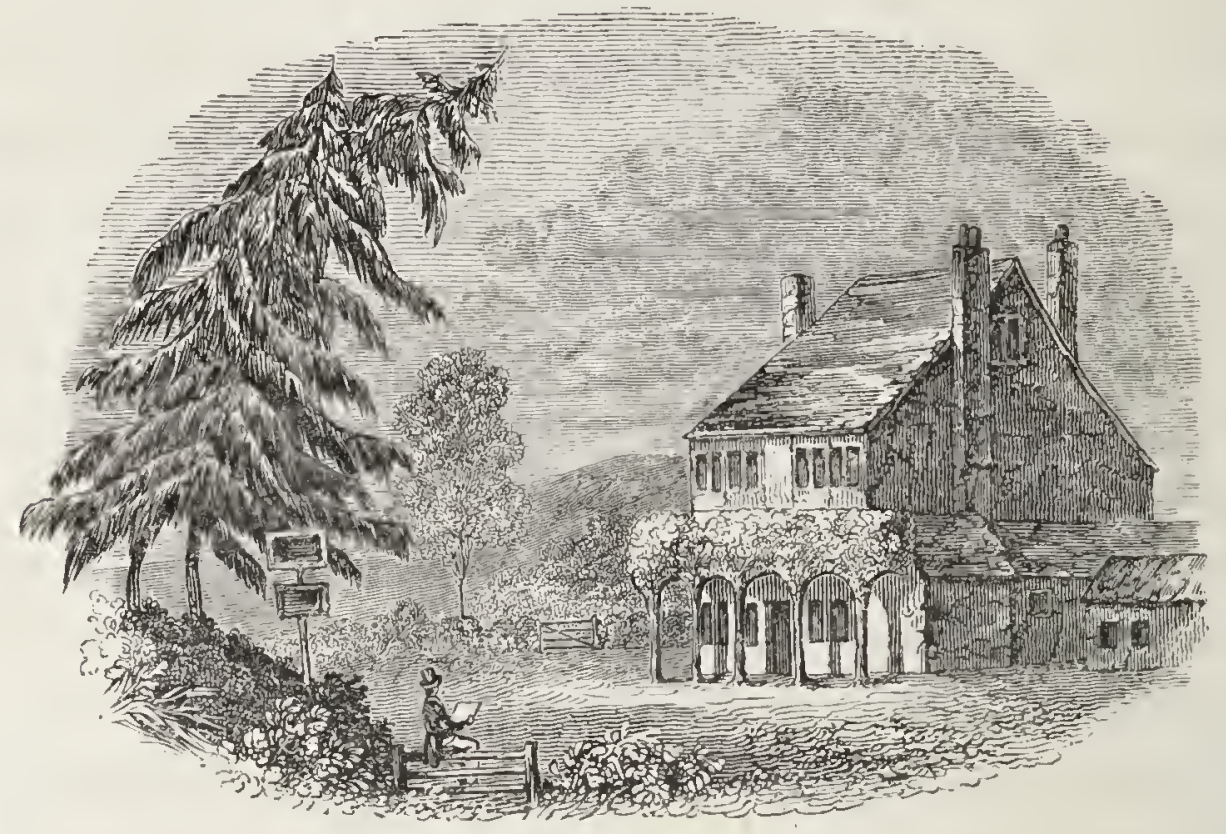

DUI.I, INY, DIRCHWOOD.

Entomologica" was laid. In Wales, in Scotland, and in Ireland, lie also took long walking tours; Paris, too, came in for a visit. In all these rambles lie was humbly studying Nature, and carefully adding to lis already vast store of information. Many of these excursions were recorded in the 'Entomological Magazine,' under the title of "Wanderings and Ponderings of an Insect Hunter." Here is one of the ponderings after a tiring day :"Then I lighted my cigar, and meditated on the past, the present, and the future. I felt myself to be standing on the very summit of a lill: before me lay the future,-an interminable, diversified region, misty and indistinct. I turned me, and looked back on the past-it was a bright, a sunny, and a goodly landscape. I gazed thereon with pleasure. Reader, dost thou ask why the past was to me so much more brilliant than the future? I will tell thee: with me the present is blessed and sanctified by content. He that pursues liis path in feverish excitement, in discontented drudgery, feasting lis imagination with dazzling views of future glory, will never look back on sucli a life as mine. He may attain the summit of his lopes, but he will attain it merely to find that it is utterly unworthy the sacrifices he has made in its pursuit. He will look back on the past as on a scene of desolation, and the 
tinsel glitter of the future he will find is tarnished." * In 1826 his parents had removed from Godalming to Leominster, in Herefordshire; and thus a fresh country was opened out. It was here that his first fernery was formed, a graphic description of which is given in the Introduction to the 'History of British Ferns.'

Notwithstanding his incessant and unwearying work in Natural History, and that a great part of his life had been spent in constant scientific study, there was no haste to rush into print, for as he limself says, "What is done prematurely has most commonly to be done twice;" and it was not until the year 1831 that his first paper was published. This appeared in the 'Magazine of Natural History,' then edited by J. C. Loudon, and was entitled-_"Polyommatus Argiolus, Melitea Euphrosyne and Selene." Let him tell the story of this first paper in his own words:- "Shortly after my return from France I became an author, a very important era in a man's existence, and one not likely to be forgotten. It was the practice occasionally to read original essays at the meeting of the Entomological Club, (which had not then a magazine of its own), and I composed and read my maiden essay. I was recommended to publish it; and with considerable coyness I consented. A mutual friend, a sort of stepping-stone in the wide gulf between me and the great editor of a magazine, undertook to hand it to the latter personage. Shall I ever forget the next magazine day? With what impatience I hastened to Paternoster Row-with what glee I laid out three shillings and sixpence-with what tremor I cut the leaves, with what eagerness I skimmed over the whole number without any previous reference to the 'contents'-with what disappointment I found that my contribution had been omitted! Another magazine day came and went in like manner; a third and a fourth, and still my invaluable contribution did not see the light. Fourteen shillings had been laid out in the hope of having my vanity gratified, and I began to feel cool on the subject, and resolved not to buy any more. It is the right way to be indifferent: the number which I did not buy contained my essay, or rather a portion of it. The editor had

\footnotetext{
* 'Entomological Mragazine,' vol. iii. p. 310 .
} 
cut it in pieces at the paragraphs, and published about half the paragraphs in a lump as a complete article; the remainder served as occasional stop-gaps for the next twelvemonth. By this sage device the connexion, or rather the brains, were completely knocked out of my essay; and, proud as we always are of our own performances, I must confess I think mine far below par. T have since wished a hundred times that it had been burnt by the editor, rather than thus mutilated; but it was my first-born, and I read and re-read it with infinite complacency, although it was so altered I could scarcely myself understand it. This was my first attempt with the public."*

Mr. Newman's attention at this time and for some few years later-until 1837-was principally devoted to Entomology; indeed, with the exception of the few short letters of Rusticus, in the 'Magazine of Natural History' (1832 and 1833), on birds, the whole of his published writings up to 1838 are upon entomological subjects. It was in 1832 , however, that he was fairly brolien to literary harness. In that year' the 'Entomological Magazine' commenced its career of usefulness: it emanated from the Entomological Club,- - a small body of gentlemen, who met socially at each other's houses on one evening in every month. This, the oldest entomological society in the country, was instituted in 1826 by Mr. Samonelle, author of the 'Entomologist's Compendium;' and he and Messrs. Davis, Hanson, and Newman, were the original members. Mr. Newman thus wrote of its formation:-- "I was not, at the period of which I am writing, a perfect novice in Entomology: "The boy is father of the man,' and from my earliest years I had been a hunter of butterflies; but the taste, during the years of adolescence, had been well-nigh dormant, until I quite accidentally met with Mr. Samouelle, in 1825. I had never before conversed with anyone who possessed so much linowledge of the subject. Mr. Samouelle, at the very time I became acquainted with him, was engaged in the formation of a social Entomological Society, and I was at once admitted a member. The first meeting of this Society, which I attended, I never 
shall forget. The slender knowledge I possessed of insects was derived from Berkenhout's 'Synopsis' and Marsham's volume on Coleoptera; but, in the course of conversation, not a single name was mentioned that I had ever read in either of these authors. I was a perfect dummy. I longed for the utterance of one sentence about 'Emperor's' or 'Admirals;' then I could have chimed in : but no, every word was entirely scientific. I resolved, before another month, to furnish myself with a little more knowledge; I procured Samonelle's 'Compendium, and went to work." * The following letter to $\mathrm{Mr}$. Hanson, dated November 9th, 1830, besides its socio-entomological interest, gives contemporaneous history:- "I came to dine with you to-day, as you say I never come; and, behold, you were 'Not at home.' I then called to enquire the price of funds, and found Englisli, 76;

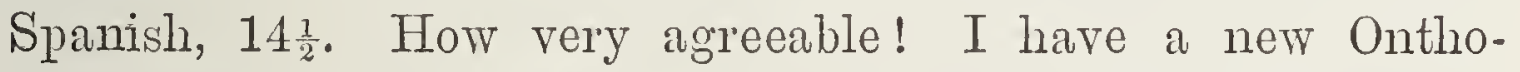
phagus (I believe), quite as black as Nutans. Poor Davis is very unwell; his shopman tells me he was confined on Saturday!!! Of course we can't expect to see lim for a month. Let Hoyer know the meeting is at Curtis's; and expect me to call for both of you at a quarter past five on Friday. If the Professor [Samouelle] has not been duly apprised thereof, you can inform him; as he is in that case sure to come to you to-night about half-past seven for seventeen eups of tea. I understand the revolutionists met in Hyde Park to-day, thirty thousand strong. You and I must shortly range ourselves under our respective standards. I shall turn you over with my sword after the first battle to hunt for Silpliciæ; if I get a new one it shall be christened, Oiceoptoma Hansonii, out of pure respect. I really (seriously) regret that this work is begun under such a patriotic and liberal-minded monarch as William; good men will hardly like to lift up the hand against lim. However, perhaps it is all for the best; the people will hardly proceed to extremes against so wise and worthy a man, whereas one less popular might meet with summary condemnation." At this time (1832) the Club consisted of the Rev. C. S. Bird, Messi's. W. Bennett, J. S. Bowerbank, William Clnisty, jun., Joln Curtis, A. H. Davis, E. Doubleday, S. Hanson, J. Hoyer, E. Newman, 
F. Walker, and J. J. Walton. Oi these fathers in Entomology all but two have passed away.

It was not surprising that such men should need an Entomological Journal. The "Introductory Address" is of considerable interest, and sets forth that the projectors anticipate no profit, but have undertaken the work "with a disinterested desire to promote the progress of a science to which they confess themselves zealously attached." Their plan is to produce "a Magazine, which shall contain Illustrations of the Habits and Metamorphoses of Insects-Descriptive Characters of New Genera and Species-Pecords of the Capture of Rarities-Reviews (with Extracts) of all New Entomological Works-and Information of every lind connected with the Science of Entomology." A worthy prospectus. Mr. Newman was chosen Editor, and threw liimself heartily into the work. In the first volume, out of sixty-three articles fifteen are from lis pen,-many written under pseudonyms,-in addition to elaborate editorial notices of new books. Amongst his writings in this volume attention may be called to the beautiful lines "On the Death of Latreille" (p. 320), as well as to the "Entomological Sapphics" (p. 432), professing to be translations from the Persian, Arabic and Greek, but in reality emanating from his genius alone: entomologists have not often been also poets. "Colloquia Entomologica," a series of articles purporting to give conversations and doings of Edward Doubleday (Erro), Francis Walker (Ambulator), A. H. Davis (Venator), and himself (Entomopliilus), are from his pen, and contain discussions in a light and pleasant vein on entomological questions. Mr. Newman continued to contribute freely in succeeding volumes, writing under various pseudonyms —“Corderius Secundus," "E. N. D.," "Rusticus," and others,as well as in his own name. The five volumes of the "Entomological Magazine' give the reader a more intimate personal acquaintance with him than any of his books or subsequent writings. It was, perliaps, a feature in liis journalism that he and his readers became at once acquaintances, and after a while actual friends; indeed, many who made his friendship through liis writings never saw lime yct have folt his loss as lieenly as 
though they had been constantly in his socicty. In addition to the members of the Club the following well-known scientific men were amongst the contributor's to the magazine:-Messr's. Babington, Dale, Douglas, Haliday, Hewitson, Shuckard, J. F. Stephens, Swainson, Waterhouse, Westwood, and Yarrell, all of whom were more or less personal friends. Edward Doubleday was Editor of the second volume, Mr. Nerwman of the other four.

It was in 1832 that Mrr. Newman's first important publication appeared, - a demy 8vo. pamphlet of 56 pp., entitled, 'Sphinx vespiformis: an Essay;' with the motto,

"All are but parts of one stupendous whole,

Whose body Nature is, and God the soul."

This clever attempt at classification created a considerable stir, and met with strenuous opposition.

In the year 1883 he was elected a fellow of the Limnean Society; and in the same year he took an active part in establishing the Entomological Society of London, which Society may be said in great measure to have sprung from the Entomological Club, then of the respectable age of seven year's. He was elected a member of the first council; $M r$. Tirby, honorary President; and Mrr. Children, President. During the succeeding years, in addition to editorial work, he wrote occasionally in the 'Magazine of Natural History,' and contributed various paper's to the above Socicties.

In the year 1835 the 'Grammar of Entomology' was published; a most useful little book. "The author" supposes his reader utterly ignorant of Entomology, and endeavours to show him that it is the History of Insects, and the Physiology of Insects, and the Classification of Insects, and the Art of Preserving Insects." This book soon went out of print.

In 1836 the laws and regulations of the Entomological Club wer'e codified; Mr. Newman was re-elected Curator, and $\mathrm{Mr}$. Walleer, Secretary; and an appeal was made for contributions of insects and books. This appeal was most liberally responded to,--many gentlemen, $\mathrm{Mr}_{\mathrm{r}}$. Newman amongst the number, giving. their whole collection; and other valuable cionations of insects wore received. So liberal were the donations that the Club 
had to choose between building a museum and paying a curator, or disposing of all but the British insects. Eventually the bull of the collection was presented to the British Museum. The second regulation is - "That the Cabinet and Library be open at the house of the Curator, 21, Union Street, Deptford, on the Friday in every week during the months of January, February, March, April, September, October, November, and December." This practice of throwing open his house to naturalists on one evening in the week was continued until 1841. From that year until 1849 the Club cabinets were under the care of Edward Doubleday and of Francis Walker. On Mr. Newman's removal to York Grove, Peckham, in 1849, he resumed the curatorship, and in 1856 the weekly assemblies. He always looked forward to the company of his friend $\mathrm{Mr}$. Jenner Weir on these occasions; indeed, it was in great measure owing to his hind assistance in after years, when health was failing, that they could be continued. In a letter to him, dated 8th September, 1856, 5.45 A. м., he writes:- "I am re-arranging the Lepidoptera belonging to the Entomological Club, and am doing this solely for the purpose of assisting beginners, who are almost daily applying to me for names. I purpose being at home at six o'clock every Thursday evening for this especial purpose. You will see that the Collection ought to be in better condition than it now is, or I shall not be so useful as I could wish. This idea is not new: I did the same thirty years ago, and continued the practice for many year's; but other cares intervened, and the cabinets went to poor Doubleday, whose generous disposition was not qualified for a curatorship, and under him the Collection became reduced to a mere skeleton,- - he gave and lent to everyone whatever they asked of him." This one night in the week was sacred to its purpose: no engagement-not even illnesswas allowed to interfere. It was always a pleasure to him to afford information, especially to young men, and they would avail themselves freely of the opportunity. Older naturalists, too, would often come, and their company was a great pleasure to him. In the earlier days this evening was no great undertalking; but in later years it was almost more 
than his powers permitted. He would come home weak and tired, and needing rest; or he may have been at home ill during the whole week: but Friday evening always found him at his post, ready to show the Collection, or patiently to name captures even if of no great interest or rarity. Of the many young men who were welcomed, few knew how a kind and courteous manner sometimes concealed bodily suffering. The Entomological Club is now in its fiftieth year; and, with the exception of the eight years mentioned above, its Collection has always been under his care, and much of his time was devoted to it.

In 1837 he abandoned the rope trade, and wrote to a relative as under:- "I am wholly without any definite prospect as regards business, having entirely given up my own, which was a very small affair. * * * I am very indifferent as to any business engagement, as it is always so great a tie, and cannot be abandoned for any length of time without something like a dereliction of duty: moreover, I think that the opportunity for enjoying life will with me shortly expire, and I am desirous, while blest with strength and health, of visiting the country, and breathing the air of mountain-wilds unchecked by the necessity of returning on a certain day. I am likely to continue a nominal residence at Deptford, securing a room for my boolss, and the insects which are now no longer mine, but of which I have the care. In the summer, if my life and health should continue, I propose wandering about the country. I have for some years turned my attention to the cultivation of ferns,- the British species only,-with a view not only to gratify myself and others with their beautiful appearance, but also hoping to ascertain, with more certainty than at present appears to exist, the distinctions between one species and another. Last summer, while at Leominster with my brother Henry, we transplanted all the ferns, which I had previously growing, into one spot, and call it a fern garden. We also added a few species collected in Wales; and I am surprised at the very great facility with which all the species may be cultivated, as far as I have tried them."

In the foregoing a record will be observed of that melancholy which, not only at this period but throughout life, at times 
beset him: it was not often of long duration, nor had it any real cause. Only a short time before, he had written :"To me long life-time, though to thee forbidden, lerhaps may be granted."

Thus showing that the erroneous idea that his life would be short had only recently been entertained.

Mention is made of a previous visit to Wales: this was just prior to the letter, in company with his friends Joln and William Christy; and of this visit he wrote in the Introduction to the 'History of British Ferns' (1840):- "It was while wandering among the Welsh mountains, in the autumn of 1837 , that I first felt any desire to know the names of ferns. I had often observed the variety that half-covered some of those black and desolate regions where fern is cut, dried and housed, as the only litter that can be obtained for loorses; but now, for the first time, I gathered liundreds of fronds, and employed the evenings in arranging them into supposed species. I found that three species were abundant in the most dreary and exposed wilds; but where some rill tumbled over a precipitous bank, or a ledge of rocks, lieeping the surface in a state of perpetual moisture, half a score others were sure to be growing. In the chasm at Ponterwyd I think I counted fourteen distinct kinds."

He was now freed from the cares and restraints of business; but no great journey was the result. Having begun to work at ferns he became fairly engrossed with his subject, as was always the case with everything he undertook. But still he was only studying, not writing, or at least not publishing; for, as has been already observed, he never published until his subject had been thoronghly grappled with and mastered. His first paper on ferns appeared, it is true, in 1838; but it was not until 1840 that the 'History' appeared, although the first edition only' reached to 104 pages.

He had always been devoted to cricket. He belonged to the Dartmouth and to the Montpelier Clubs, on Blackheath; and now, with more leisure, more time was deroted to the game. Some of his naturalist friends were members of the Dartmouth Club, as was also the famous "Felix" (Mr. Wanostrocht), the 
great cricketer of his day. Mr. Newman had a strong "defence:" on one occasion having gone in with the reclonbtable "Felix" against an almost hopeless score, and remained in until the runs were made and the match won, he was presented by "Felix" with a bat in commemoration of the feat. Two other bats bear tribute to his prowess. This love of cricket he always retained; and he was frequently to be seen at the Oval or at Lord's on the occasion of great matches.

In June, 1839, he went to Ireland, whither he had been with his friend William Bennett a year or two previously. Starting alone from Newry, lnapsack on back, he went northward, throngh Belfast, round the sea-coast of Antrim to the Giant's Causeway; on round the north and north-west coast to county Mayo, where he rested for a time at Achill Island and Clew Bay: here in getting put across to the island he badly injured his leg, which accident sadly interfered with the pleasures of his future walling. Tlirough Connemara, Clare, Kerry, Cork, Waterford, Wexford, and Wicklow, he made his way, mintil the tour finished at Dublin, in August. Throughout the whole trip he had paid especial attention to ferns, and collected a mass of information concerning them. But every natural object, in whatever branch, was of interest to his cultivated mind; and in tine "Notes on Irish Natural History" (1840), entomological, ornithological, and botanical observations, generally, are to be found.

December of the same year found him still without a business, but working hard at the 'Ferns;' not only writing the letterpress, but drawing the illustrations; for the whole of the beautiful drawings which illustrate it-figures, tailpieces, and landscapes -are the product of his careful pencil. Especial attention should be called to the fern scutcheon, with the motto, "Elegantia et Humilitate," which appears on the title-page of the second and third editions. The book was published early the following year, and was soon ont of print. It was printed by George Luxford, the printer of the 'Magazine of Natural History,' which Mr. Newman was then temporarily editing, and thus they were associated. The 'Ferns' having gone off so well there was inducement to publish other books. Mr. Luxford was 
a botanist and of literary ability, and therefore somewhat of a congenial spirit. Mr. Newman was about to be married, and in want of a business. The idea, therefore, occurred to effect a partnership, and print his own books. This was done; and he once more commenced business-this time as a member of the firm of Luxford \& Co., Printers, Ratcliff Highway, at the sign of the "Bouncing B." On the accession of an entomological partner the " $B$ " received an insect shape, and was used as a trade-mark. Next year, however, Mr. Luxford was bought out of the business; and the printing-office was removed to Devonshire Street, Bishopsgate, where Mr. Newman conducted it until 1870, when he retired from business in favour of his son.

In June, 1841, the 'Phytologist' - a monthly botanical magazine-was started, and was conducted with great spirit for some years: Mr. Luxford was editor; but Mr. Newman wrote frequently, and was responsible for the work. It was never commercially successful; and on the death of its editor, in 1854, it came suddenly to an end. Dr. Trimen, writing in the 'Journal of Botany,' remarks:- "The thanks of British botanists are due to Mr. Newman for the possession of that valuable repertory of the progress of their department for thirteen years."

After his marriage, Mr. Newman resided for two years in Wellclose Square, being then a near neighbour of Mr. N. B. Ward, whose beautiful, "closely-glazed" fernery, in one of the worst parts of London, was a constant delight. The "stitching parties" at Mr. Ward's brought together many botanists.

Mr. Newman having now settled down to a business more congenial than either of the former ones,-namely, printing books on science,- - he gave up his country wanderings, and went to work in earnest. But although thus closely occupied he was by no means debarred from his scientific studies. In 1840 the 'Entomologist' had been commenced, taking the place formerly occupied by the 'Entomological Magazine,' Mr. Newman being Editor, and contributing freely. In 1841 he published the 'History of Insects,' of which he says:- "This little book was observed as a caterpillar, in 1835; in 1837 it disappeared, and 
remained concealed as a quiescent and lethargic pupa, until, roused by the genial influence of the present spring, it has burst its cere-clotlis, and assumed the ornamented wings of a gay and volatile butterfly."

At the end of 1842 the 'Entomologist' was discontinued; but with January, 1843, commenced the 'Zoologist,' of which the founder lived to conduct an uninterrupted series of thirty-three annual volumes, - a circumstance probably without parallel in the history of journalism throughout the world. He would often look at the row of red volumes on his bookshelves with a quiet pleasure, not unmixed with a certain pride. The following extract from the Preface to the first volume gives, in his own words, an idea of the character and scope of the journal:- "The attempt to combine scientific truths with readable English has been considered by my friends as one of surpassing rashness; and many have been the kind and pressing solicitations I have received to desist from a labour so hopeless; many the supplications to introduce a few Latin descriptions, just to give the work a scientific character. In reply to my friends, I would beg to instance White's 'Selborne.' That most delightful of histories is written in pure, plain, intelligible English, and has found ample favour in the eyes of the public. White is now no more; but his mantle has fallen upon other's: a multitude of observers have arisen in the same field, and, what is more to my purpose, have become contributors to the pages of the "Zoologist." Nature herself is exhaustless; our field of observation is wider, a thousand-fold, than White ever enjoyed; our capacity for observation is certainly not less. These are the grounds I have for hoping that the "Zoologist' will succeed." The practice of writing Natural History in simple English, thus rendering it interesting even to those not deeply versed in Science, was one on which Mr. Newman strongly insisted. In the lists of contributors to the pages of the 'Zoologist' appear the names of almost every British naturalist of note.

In 1844 the second edition of the 'Ferms' made its appearance, the first having gone rapidly out of print. In the second edition the work had increased from 104 to 424 pages. The Equisetacer and Lycopodiacere werc added, as was also such a 
mass of additional information that the work was almost rewritten, and hardly to be called a second edition, deserving to rank as a new book. From this time-with the exception of the collected 'Letter's of Rusticus' (1849)-until the publication of a third edition of the 'Ferns,' in 1854, he brought out no new book, his time and thought being sufficiently occupied with business and with editorial duties. There is no volume of the 'Zoologist' that does not contain numerous articles from his pen: these are upon Entomology, Ornithology, and other branches of Natural History; and many are of considerable importance. With him it was not sufficient to work out only one branch of a science, or even all the various ramifications of that one science: with whatever he undertook he made himself thoroughly familiar. He had taken up the study of Natural History, and everything connected with it was of interest to him,--whether Quadrupeds, Birds, Reptiles, Fishes, Insects, or Plants; he was familiar with every branch of every subject.

In the year 1850 he read before the Zoological Society, an ingenious paper proposing a new Physiological Arrangement of Birds. The new system, however, met with slender support, and considerable opposition.

An essay "On the Employment of Physiological Characters in the Classification of Animals," the result of most careful thought, was published in 1856. These two papers are full of information, and the reasoning is very acute. Some naturalists are still of opinion that $M r$. Newman's views have been too much disregarded by modern systematists, especially as to the proposed division of birds into two great groups, viz. Hesthogenæ and Gymnogenx: the former containing those birds which produce their young ciothed with down, eyes open, and capable at once of running and feeding themselves; the latter, those birds which produce their young naked, blind, and helpless.

The 'Insect Hunters,' or Entomology in verse, appeared anonymously in 1858: it was written for beginners, and gives an insight into the hidden mysteries of the science in simple language. The author discourses pleasantly to a young friend on "The Four Stages of Insect-life:" "Metamorphosis;" 
"The Scale Wings;" \&c. The Preface to the first edition is brief enough and pretty enough to be quoted entire:-

"Just as the butterfly, cliild of the hour,

Flutter's about in the light of the sun,

Wandering wayward from flower to flower,

- Sipping the honey from all, one by one:

So does the fanciful verse l've created

Love 'mongst the experts in Science to roam,

Drinking their spirit without being sated,

Bringing the sweets of their intellect home."

Although anonymous, the author was at once suspected. The book was quickly out of print; and a second edition, bearing the author's name, was published in 1860. In this appeared several other poems, written at an earlier date.

In 1858 Mr. Newman became Natural-History Editor of the 'Field,' and continued to hold that post until his death. The Natural-History department of that paper, however, largely increased, and other editors were added. Amongst his papers in the 'Field,' those on economic entomology are of the greatest value; and there can be no doubt that it will be long before his "life-histories" are superseded. Amongst the master-pieces are those of the goat-moth; gooseberry grub; turnip grub; daddy-longlegs; and pear-tree slug: these valuable contributions were continued to within a month of his deatl, as a column and a half of the 'Field' for May 13th, 1876, is taken up with his "Life-history of the Sandfly, or Simulium." He wrote of these papers:- "My object in penning these notes is to bring the creature face to face with his victims; for unless we know our enemy-his appearance, his ways, and his whereabouts-all our attempts to compass his destruction must be futile." Before his time it was usual to consider all insects found on plants as "blight," and to purchase some proffered nostrum in order to destroy them. No one seemed to consider it possible that some insects might be useful, seeing that others were so obviously hurtful; and the friends and foes, the allies and enemies of the cultivator came in for a like share of indiscriminate approval, or the reverse, according to the whims of the individual or the folk-lore of the locality: the balance of Nature was then, as now, but little regarded. These papers on 
the practical application of Entomology were written principally for the instruction of agriculturists, horticulturists, and arboriculturists. The necessity for these was great; but, after the twenty year's' teaching of a Newman and a Curtis, practical Entomology lias but just commeuced to put forth its fruit-buds. The articles on the inmates of the Crystal Palace Aquariumpopularly written, yet full of information-are also worthy of considerable attention.

From 1858 to $1861 \mathrm{Mr}$. Newman was engaged on a series of articles in 'Young England' on Insects and Birds. At the same period he acted as Natural-History Editor of the 'Friend' for about two years, writing a column or two in each month's issue of that newspaper.

In March, 1861, Mr. Newman had the gratification of receiving a Testimonial-consisting of scientific books-from about seventy gentlemen, in "ligh appreciation of services rendered in the promotion and diffusion of scientific lnowledge." Mr. Newman had very properly refused to allow his own journal to be used as a means for advertising the testimonial to himself, and by this action many were led to believe that the project was distasteful, and held aloof. The boolis, however, besides being of great use and pleasure to the recipient of the testimonial, were highly appreciated by liis Friday-night visitors. A full liistory of the transaction will be found in the 'Zoologist' for 1861 (Zool. p. 7457), but modesty seems to have prevented it being indexed.

Mr. Newman's writings had of late years assumed a more ornithological complexion; and in 1861 his small work entitled 'Birdsnesting, being a complete description of the birds which breed in Great Britain and Ireland,' made its appearance.

Three year's later, however, he was once more engaged on the old favourite subject-the 'Ferns.' The price of his beautiful book was necessarily comparatively high ; and many low-priced fern books, by other writers or compilers, had made their appearance. In order to compete with these, a fourth edition of 'Britisls Ferns' was published in 1864: it was of smaller size and considerably lower price, and illustrated with steel-plates instead of by woodcuts, as in the former editions. In the 
Introduction, which, as well as that to the former editions, may be noticed as among the most cliarming of Mr. Newman's writings, he says:- "It becomes necessary to notice-just to show that I am aware of-the fern books that have sprung up around mine, like mushrooms around the parent plant. I have read them all: I have thought this a duty, and have performed it; and I unhesitatingly pronounce, with the German critic, that in all the mass of fern literature that owes its existence to my various editions, "What is new is not true, and what is true is not new.' It is, however, a great satisfaction to me to believe that the study, originated by myself, has been a source of profit to others, and that their emulative industry has conferred no injury on myself."

The 'Zoologist' had, since 1860, been growing more and more bulky: double uumbers were frequently resorted to, and yet space could not be found for all the worthy communications that were received. In order to cope with this embarras de richesses, the 'Entomologist,' which had been merged in the 'Zoologist' in 1843, resumed its separate existence in 1864. A large part of the entomological communications at once went over to it, and the difficulty was at once satisfactorily met. From that time the 'Entomologist' has been steadily increasing in public estimation; and its circulation is, for a purely entomological periodical, unprecedentedly large.

Mr. Newman had long felt the want of a book of reference on British birds. Montagu's 'Ornithological Dictionary' was a most valuable book, but it was lialf a century out of date; it had long been out of print, and was very scarce. The idea occurred that what was a desideratum to himself must certainly be so to others. The fourth edition of 'British Ferns' being now completed, and the 'Entomologist' fairly launched, he at once set to work. With the help of Selby's 'Illustrations of British Ornithology' (1833), Yarrell's ' History of British Birds' (1856), the 'Zoologist,' and the 'Field,' he laboriously brought the work up to date, giving a reference to Yarrell's figure of the bird, and Hewitson's figure of the egg. The editorial additions are naturally very great, and are separated from the original by editorial brackets. The 'Dictionary of British Birds,' a demy 
8vo, extending to 400 pages of small type closely printed, was published in 1866.

On its completion, Mr. Newman made preparations for continuing the 'Illustrated Natural History of British Moths,' which was commenced in 'Young England.' Five numbers (80 pp.) had been brought out by $\mathrm{Mr}$. Tweedie, in direct contravention of Mr. Newman's wish, and without his lnowledge: for these five numbers, written at a much earlier date than the remainder and not printed under his supervision, he never would hold himself responsible. It will be seen at once that they are incomplete, and stand sorely in need of the care bestowed upon the rest of the work. Mr. Newman was eventually induced to continue the worl, and having once consented he, as usual, laboured with all his heart. The descriptions of the perfect insect and of the larva are most careful and accurate, indeed almost microscopic. The figures, of which there are more than eight hundred, were drawn and engraved under his own superintendence. In all his former works the woodcuts had been drawn by himself, and engraved by $\mathrm{Mr}$. Kirchner; but now the allotted span of life was nearly reached, and his artistic power's had failed. The engraver was the same, however; and the beauty and accuracy of the figures are in great measure owing to his care and slill. This book came out in monthly numbers, the last one appearing in June, 1869, when the complete volume was published.

Mention may here be made of Mr. Newman's talent for caricature. By a few touches he would produce a portrait, which could not fail to be recognised. The mirth it produced would be renewed when, as was sometimes the case, one of the company would remark, "But it is not at all like" So-and-so,no name having been previously mentioned. One or two of the cartoons in 'Punch' have been from his designs. His pen was as ready with satire as was his pencil; witness the following "specimen of a new dictionary," which he ascribed to one of his friends :-

"Science signifies crude guesses to explain phenomena observed; thus, when Professor Westwood explains the evaporation of salt to admiring satellites lumbly lineeling 
round him,-like the spectators of the Nabob eating Batty's pickles, - it is science.

"Nescience, is when a man devotes his life to informing" others, and his name is tabooed in all scientific circles." A sketch accompanies the manuscript in the original.

Immediately upon the conclusion of 'British Moths' (486 pp. super-royal 8vo), the companion work was commenced,'An Illustrated Natural History of British Butterflies' (1871), on which even greater care was evinced, as especial attention was given to geographical distribution. These two works form the text-book of British Macro-Lepidoptera.

'British Butterflies' was written in Mrr. Newman's seventieth year, and was his last complete work. Two year's previously he had retired from business, but by no means from labour. He was at first actively engaged on the above-mentioned work, and on its completion the 'Zoologist,' the 'Entomologist,' and the 'Field,' kept him fully occupied. He was often to be seen at the Crystal Palace Aquarium, and the result of the visits is to be found in various papers in those joumals. In the year 1868 he had built an aviary in his garden, and this was a constant source not only of recreation, but of study. There he would sit, until the birds became so tame as to fly to him on his entrance and feed from his hand. In "Notes of my Bird Cage" (Zool. S. S. 3157) will be found an account of his success in breeding the little Australian parrakeet (Melopsittacus undulatus): he possessed upwards of thirty at one time, all bred in the aviary. A diary of the birds, after the manner of Gilbert White, was carefully liept, and short notes frequently appeared in the magazines. He had a great affection for all living animals, and could not bear to see anything suffer, even for its own good. He frequently visited the Zoological Gardens, always intent on gaining information; and in his later years was earnestly at work on a new classification of birds. One of his friends writes, with reference to these visits to the Zoological Gardens, and to the proposed classification of birds which he did not live to complete, and of which but few fragments remain:- "For forty year's a visit to the Zoological Gardens has been one of my greatest enjoyments; but with Mr. Nerwman, 
who was my frequent companion, the pleasure was very much enlanced. He would stand to watch the movements of that remarkable bird, the Cariama (Dicholophus cristatus); its position amongst birds was to him a puzzle, but he at last, I am inclined to think, regarded it as a Raptorial bird, as classified by Mr. Sharpe, of the British Museum. He attached great importance to the mode by which a bird progressed on the ground, and he exhibited almost a childish delight when he first observed that eagles hopped. Natural History was to Mr. Newman not only an intellectual scientific study, but was also an absorbing passion." He was at this time devoting as much attention to Entomology as to other branches of Zoology, making an especial study of the Gallfies and their productions, of the Sawflies, and the Bees,-the latter chiefly with a view to observations on the fertilisation of plants by their agency. His "Collected Observations on British Sawflies" were laid aside for years, and their revision and publication in the 'Entomologist' was only commenced shortly before his death. It is hoped that further instalments may yet appear, containing his later views on a natural classification of Insects, - a subject which had continuously occupied his thoughts since 1834.

The end was now drawing near. In February, 1873, he had had a severe illness, from which, although unknown to all but himself, he never entirely recovered: it preyed upon his spirits, and lessened that mental grasp which had hitherto characterized him. The few of his old friends that were left were one by one departing, and he keenly felt their loss. On October 24th, 1874, he wrote to Mr. Jenner Weir the following touching letter:- "The death of my friend, Mr. Walker, has been a blow from which I can never hope to recover: he was my right hand in all the difficult branches of Entomology; and, more than that, he was a constant friend. I feel alone in the world now that he is gone,-alone as regards literary labour. I cannot hope for a much longer lease of life; but I have been thinking I should like to republish my views about birds, because at the time I sketched them Huxley's views and Garrod's views were non-existent, and Nitsch was all but unknown in England; the 
last-named is invaluable, it contains such a mass of facts. I now am very, very old, and very, very weary, and I feel that my race is almost run; and as I try to sketch a brief notice of $\mathrm{my}$ departed friend, I think how soon will some one be doing the same for me: for some one will surely do it,-for better or worse, for praise or blame." Again, with reference to the Classification, on January 11th, 1875:-_" It is evident that the learned pundits will not consent to the removal of the cranes, bustards, \&c., from their usual locality, which is my special object. I am endeavouring to get out a second edition of my Classification, and thus leave it on permanent record. I mentioned last time I saw you that all gymnogenous birds perch, even herons. I observe another character that seems singular : all the aquatic gymnogenous birds are shy of using their webbed feet for swimming; terns, gulls, albatross, storm petrel, frigate bird, tropic bird, \&c., are seldom seen swimming; geese, duclis, divers, swans, \&c., prefer settling on the water. I have never seen a gymnogen settle on the water, nor a hesthogen on land." Soon after this came the death of Mr. Doubleday, with whom he had been in constant-at one time almost daily-correspondence for very many years. The following letter was written on the 30th of June, 1875:-_" Our poor friend Doubleday is dead. He died yesterday morning at seven o'clock, and without much suffering; for the last few days there had been no prospect of his recovery. With him has died a larger amount of Natural-History knowledge than has ever been possessed by any one of our countrymen. What a pity that it should be lost for ever. He was so reluctant to write that I believe he has left no documents behind him that will bear any evidence of the amount of his knowledge."

Towards the end of May, 1876, Mr. Newman again became seriously ill; and although at first it was thought that with his vigorous constitution lie would overcome the lisease, as lie liad done previously, he became worse. Further surgical assistance was called in, but to no purpose; and on the 12th of June, 1876 , acutely conscious to the last, he passed peacefully away. In his last illness he was patient, and without care or any anxiety. He was interred at Nunhead Cemetery. 
Mr. Newman was a Fellow of the Linnean and Zoological Societies, of the Royal Microscopical Society, and of the Zoologico-Botanical Society of Vienna; he was also an original member and, in 1853-4, President of the Entomological Society of London; an honorary member of the Entomological Societies of France and Pennsylvania, of the Botanical Society of Edinburgh, and of several minor societies: but the only title on which he set value was that of Academiæ Cæsareæ Naturæ Curiosorum,-the Imperial Academy of Leopold Charles of Austria, consisting of the forty most distinguished naturalists known to the council throughout the world; each takes the cognomen of one of the original members, - - his was that of "Latreille." Membership of this learned body conferred the title of Doctor, but he was too modest to use the title. Ostentation of every kind was distasteful to him, and he derided it in others; indeed, he prided himself on the opposite extreme, and his manner of life was especially simple and retiring.

In addition to the works mentioned above there appear in the Royal Society's list of detached papers to 1860 , under the name of Edward Newman, the titles of one hundred and thirtyone completed papers. These are only the more important of his writings. To these may be added the anonymous articles published in the 'Entomological Magazine,' as well as those written in an editorial capacity, and numerous occasional notes. Since 1860 the number has probably been doubled, so ceaseless has been the industry of his pen.

The following extracts, from kindly letters, may fittingly be appended to this memoir, and are but types of many :-

"His loss is no common one, for all who liave known him for" so many years, through his writings and as a correspondent, can testify to the invariable and ready way in which he imparted information: he has done more in his long life of usefulness than any of his contemporaries to foster and encourage a love of natural science. The 'Zoologist,' alone, will ever remain a monument of his indefatigable industry; and, as a storehouse of facts for the working naturalist, will be continually quoted in all future works bearing on its special branches of English Zoology." *

* Mrr. John Cordeaux. 
"Whether we consider the late Mr. Newman's high attainments as not only a naturalist, but a leader and trainer of naturalists in so many departments of physical science, or whether we remember his unequalled familiarity with the entire history of its wonderful development in the course of the past half-century, we must all feel his death as a sort of personal bereavement. It was a very charming characteristic in him that he was always so willing to stoop down and hold the ladder for younger men who were climbing up."*

"We, his friends and admirers, have lost one whose equal we may vainly seek, for he was a man of wonderful power of mind, of great judgment, a profound thinker, an able writer; and, from lis great experience in editorship, better qualified than any of our naturalists for conducting a popular journal like the 'Zoologist.' Ever ready to instruct and encourage, too, the student of Nature; never censorious or dictatorial, though his patience at times must have been sorely tried." +

"The name of Edward Newman is inseparably associated witl the list of those who have themselves advanced natural science, and who have done all in their power to help and encourage other's in the field in which they have so successfully laboured." +

"It has lately been said of Ancrea Cesalpino that he did great gool service in his day, catching up the lamp of linowledge from the hands of his forerunners, and passing it on brighter and better trimmed to those of his successors; these words are especially applicable to $\mathrm{Mr}$. Newman. Necessarily his extended observations led him into the subject of classification ; for what is more likely to take hold of the mind of a field-naturalist-which Mr. Newman pre-eminently was-than the analogy of different species, their form, structure, manner of living, and unity of habits? Hence an inquiry into the uniformity and design of creation. It is to the Newmans to whom we must look for a natural system of classification; one, so far as relates to the Insecta, not arbitrarily founded on the form, colour, or markings of the imago, but on their affinities, as exhibited in the external form and internal structure of their various states. For the - manner in which these evidences of analogy were weighed by

* Rev. S. H. Saxby, + Capt. Hadfield. † Mr. Frederick Smith. 
Mr. Newman, witness his writings, from 'Sphinx Vespiformis' to his notes on the subject in his 'Collected Observations on British Sawflies,' revised and corrected by the trembling hands of the last month of his life." "

"There are few branches of Natural History which have not been ably elucidated by his active and accurate powers of observation. He not only thus advanced the interests of scientific Natural History, but he induced others to emulate his own good deeds by inciting them to follow the examples he continually placed before them, and by recording their labours in the highly useful and valuable serial publications that he continued to edit to the termination of his labours and his life. Few naturalists have done so much, and in so modest and unpresuming a manner, to diffuse a taste for the Natural History of his country as my late much respected friend Edward Newman. He was esteemed and valued by all who knew him. His life was usefully and honourably spent in the pursuit and dissemination of knowledge; and the results of his labours, as published, are a more durable and honourable monument than either bronze or marble." + .

\footnotetext{
* Mr. Edward A. Fitch.

+ Dr, Bowerbank.
}

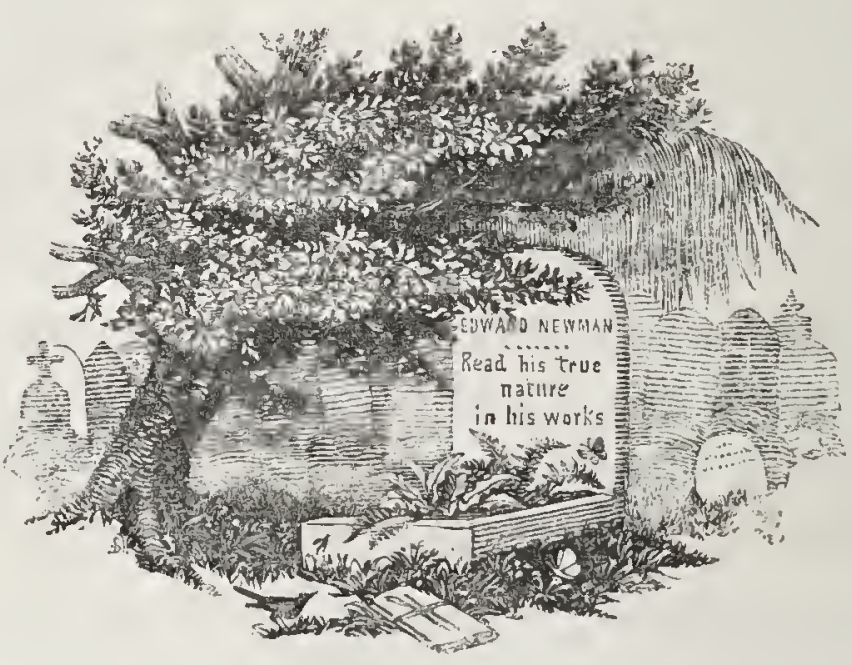


CRYPTOGAMIC MICROSCOPICAL SLIDES. - Slides of various CRYPTOGaMIC PLANTS will be carefully prepared by J. E. VIzE.

Subscribers may obtain the above from the Rev. J. E. VizE, Forden Vicarage, Welshpool, on forwarding Post Office Order for 2I/ for 24 Slides, and 6d. for Postage and Box. They can have their own specimens of Ferns, Fungi, Lichens, Mosses, \&c., prepared, if desired.

\section{REVUE ET MAGASIN DE ZOOLOGIE}

PARAIT UNE LIVRAISON CHAQUE MOIS.

et forme chaque année un fort volume in 8vo. de 500 pages et 30 planches environ.

23 francs par an ( $20 \mathrm{I} 8 \mathrm{~s} 6 \mathrm{~d}$, post free).

Ce recueil fondé en I83I par M. Guerin Menevill èst toujours sous la direction scientifique de ce celèbre auteur. Il contient un grand nombre de travaux inédits sur toutes les branches de la zoologie, et des comptes-rendus des ouvrages nouveaux ayant trait à cette science.

Les abonnements pour l' Angleterre doivent étre adréssé à Mr. Boucard, 55 Great Russell Street, W.C., London; pour les autres pays, chez Deyrolle fils, 23 rue de la Monnaie, Paris.

On the 1st of every Month, 32 pp. 8vo., with at least one Plate,

\section{THE JOURNAL OF BOTANY - British and Foreign.}

Edited by Henry Trimen, M.B., F.L.S., British Museum, assisted by J. G. BAKER, F.L.S., Royal Herbarium, Kew.

Subscriptions for 1876 (I2s, post free, in the United Kingdom) payable in advance to the Publishers, Messrs. Ranken \& Co., Drury House, St. Mary-leStrand, London, W.C., of whom may be obtained the volume for 1875 (price $16 \mathrm{~s}$ $6 \mathrm{~d}$, bound in cloth); also covers for the volume (price Is) and back numbers.

\section{THE OANADIAN ENTOMOLOGIST:}

\section{A Monthly Publication on Insects, issued by the} ENTOMOLOGICAL Society of CANADA.

Subscription: Five Shillings stg. for volume of 12 numbers, free of postage. Address-Rev. C. J. S. BETHUNE, Trinity College School, Port Hope, Ontario, Canada.

On the rst of every month, Price Sixpence, 24 pp. 8vo.,

\section{THE ENTOMOLOGIST'S MONTHLY MAGAZINE,}

Conducted by F. W. DOUGLAS; R. M'LACHLAN, F.L.S., Sec. Ent. Soc.; E. C. RYE, and H. T. STAINTON, F.R.S., \&.c.

This Magazine was commenced in 1864 , and its pages are principally devoted to information respecting British Entomology.

London: John Van Voorst, I Paternoster Row, E.C.

N.B. - The volumes commence with the June number in each year. Subscriptions (6s per rol, post free), should be forwarded to the Editors, at the above ardiress. 


\section{TO NATURALISTS AND OTHERS.}

As I am at present working at the Hemiptera of the world, I should be very much obliged for specimens from any part. For the benefit of those who may kindly wish to help, I give a few hints on the collection and preservation of this neglected order of insects. Hemiptera (which include the various insects popularly known as Plant-bugs, Tree-hoppers, Cicadas, Fireflies, Aphides, \&c.,) resemble in general appearance Beetles, but have more membranous upper wings (or wing cases), and are usually of softer consistence, besides having their mouth provided with a rostrum, or proboscis, instead of jaws. In size Hemiptera vary from an inch or more to less than one line in length. In colour they are also variable, some being exccedingly brilliant, others very obscurcly coloured. They inhabit trees, shrubs, and low plants; some run about on the damp margins of streams and lakes, some inhabit the surface of the water, and others swim in the water or crawl on the mud below. A few live under the dead bark of trees, and are usually flat and dull coloured. The best mode of catching those on trees and shrubs is by shaking the branches over an inverted umbrella; those that are found on or under low plants (grass or other herbage) may be collected by sweeping the herbage with a net (which can casily be made out of a ring-12-I8 inches in diameter - of stout wire, attached to a stick, and having a bag of canvas sewn on to it). They may also be found by searching on flowers and leaves. Those at the margin of the water may be folind by searching; those on and in the water by using a net similar to the sweeping one, but xvith canrass open enough to allow the water, but not the insects, to pass through. Rather shallow, still water, among weeds, or in open places among wecds, are the best situations. Many species fly into houses at night, attracted by the lights. In habits these insects are variable : some move slowly, others run or fly with celerity, and others (treehoppers, \&c.,) jump with great aciivity. As many species closely resemblc each other, it is desirable that all specimens met with should be secured. It is also desirable that small species as well as large ones should be collected, as it is among the former that most undescribed forms may be expected. To kill and preserve these insects all that is necessary is that on capture they are put in a bottle filled with spirits of wine (rum, whisky, sc., will do). Care must be taken, however, that the bottle is kept filled with fluid, otherwise the specimens will be shaken about and broken. So in transit great care must be taken to guard against the evaporation of the spirit. The bottles, if not filled to the top with specimens, should have the empty space filled with crumpled pieces of paper, then filled with spirit, and tightly corked - all the bottles may then be packed into a larger one, or jar, also filled with alcohol, and tightly corked.

In return for any specimens (few as well as many) kindly sent to me 1 shall be happy (if wished) to return named specimens, or to give in return named British Lepidoptera, Coleoptera, Hemiptera, or Flowering plants; or in certain cases I shall be glad to buy specimens.

Communications may be addressed to

\section{Dr. BUCHANAN WHITE,}

PERTH,

SCOTLAND. 